\title{
Kepatuhan Minum Obat Pada Pasien Lupus Eritematosus Sistemik di RSUP Dr. Hasan Sadikin Bandung
}

\author{
Shiane Hanako Sheba, ${ }^{1}$ Henni Djuhaeni, ${ }^{2}$ Budi Setiabudiawan, ${ }^{3,}$ Deni K. Sunjaya, ${ }^{2}$ \\ Kuswandewi Mutyara, ${ }^{2}$ Fedri Rinawan ${ }^{2}$ \\ ${ }^{1}$ Yayasan Syamsi Dhuha Bandung, Indonesia, ${ }^{2}$ Departemen Ilmu Kesehatan Masyarakat Fakultas Kedokteran \\ Universitas Padjadjaran Bandung, Indonesia, ${ }^{3}$ Departemen Ilmu Kesehatan Anak Fakultas Kedokteran \\ Universitas Padjadjaran/Rumah Sakit Dr. Hasan Sadikin Bandung, Indonesia
}

\begin{abstract}
Abstrak
Lupus eritematosus sistemik (LES) merupakan penyakit autoimun kronik yang mengharuskan penyandangnya minum obat dalam waktu lama bahkan seumur hidupnya. Keadaan ini selain menimbulkan dampak fisik, psikis maupun sosial juga menyebabkab biaya tinggi sehingga LES digolongkan sebagai penyakit catastrophic. Ketidakpatuhan minum obat penyandang LES akan berpengaruh langsung terhadap memburuknya outcome penyakit lupus. Penelitian bertujuan mengeksplorasi pelaksanaan dan kepatuhan minum obat pada pasien LES dengan harapan terjadinya perbaikan penatalaksanaan LES yang berdampak pada peningkatan kualitas hidup serta penurunan angka kematian karena LES. Telah dilakukan penelitian kualitatif terhadap 6 informan pasien LES suku Sunda di klinik reumatologi RSUP Dr. Hasan Sadikin Bandung pada bulan Juli sampai September 2016 dengan menggunakan pedoman wawancara mendalam open question yang dikembangkan sesuai dengan jawaban informan. Paradigma penelitan adalah constructivism dengan triangulasi terhadap 2 orang keluarga pasien dan 3 dokter konsultan klinik reumatologi RSUP Dr. Hasan Sadikin Bandung. Data yang diperoleh dianalisis secara bertahap melalui proses transkripsi, reduksi, koding, kategorisasi, penyusunan tema, interprestasi data serta pembangunan konsep. Hasil penelitian menunjukkan ada 57 koding, 14 kategori, dan 3 tema yang mengarah kepada kepatuhan minum obat pasien LES. Ke-14 kategori kepatuhan tersebut terdiri dari: karakteristik individu, daya ingat, pengetahuan, eksperimen, dan manajemen konsumsi (faktor predisposing); karakteristik penyakit, karakteristik obat, biaya, kebijakan rumah sakit, akses ke rumah sakit, terapi alternatif dan enabler agent (faktor enabling); karakteristik tenaga kesehatan dan dukungan eksternal dari berbagai pihak (faktor reinforcing). Konsep dan konstruk yang ditemukan membangun konstruk lokal Jawa Barat berlatar belakang karakteristik masyarakat Sunda dan bersifat kontekstual terhadap penyakit lupus.
\end{abstract}

Kata kunci: Kepatuhan minum obat, lupus eritematosus sistemik, odapus

\section{Drug Adherence Drug in Systemic Lupus Erythematosus Patients in Dr. Hasan Sadikin General Hospital Bandung}

\begin{abstract}
Systemic Lupus Erythematosus (SLE) is a chronic autoimmune disease that requires prolonged treatment. SLE creates physical, psychological, social, and economic burden for the patients; therefore, it is categorized as a catastrophic illness. Non-adherence to medication in SLE patient isan important factor that directly leads to poor outcome. The aim of this study was to explore the management and adherence of patients with SLE to improve the quality of life and to reduce the mortality rate. A qualitative study was undertaken to 6 sundanese SLE patients at the Rheumatology clinic in Dr. Hasan Sadikin General Hospital Bandung in July-September 2016 by using open-ended questions in in-depth interviews with probing based on informant answers. The paradigm used was constructivism with triangulation to family members of 2 patients and 3 rheumatologist consultants in Dr. Hasan Sadikin General Hospital Bandung. Data collected were analyzed gradually through transcription, reduction, coding, categorizing, theme analysis, data interpretation, and theorizing. The results showed 57 codes, 14 categories, 3 themes that focused on the medication adherence of Lupus patients. The themes were categorized as predisposing (individual characteristics, memory, knowledge, experimentation, and consumption management), enabling (drug characteristic, cost, hospital policies, access to hospital, alternative therapy, and enabler agent), and reinforcing (characteristics of health care professionals and social support) according to the predetermined theory. This study has also identified the local concepts and constructs Sundanese people in West Java, which is contextual to the lupus disease.
\end{abstract}

Key words: Adherence, systemic lupus erythematosus, odapus

Korespondensi: Shiane Hanako Sheba, dr., MKM, Yayasan Syamsi Dhuha, Jalan Ir. H. Juanda no.369, Komp DDK No.1 Bandung E-mail: shianehanako2014@gmail.com 


\section{Pendahuluan}

Kepatuhan minum obat pada lupus eritematosus sistemik (LES) sebagai penyakit kronik yang belum diketahui penyebabnya, serta diperberat dengan berbagai comorbidities, masih menjadi perhatian karena berpengaruh pada perjalanan penyakit dan biaya yang ditimbulkan., ${ }^{1,2}$ Orang dengan lupus (odapus) harus mengonsumsi berbagai jenis obat seumur hidupnya yang bertujuan meningkatkan kualitas hidup. Dipihak lain pengobatan tersebut dapat menimbulkan efek samping serius yang dapat memperburuk kondisi kesehatan odapus. ${ }^{3}$ Keadaan tersebut yang menyebabkan ketidakpatuhan minum obat pada penyandang LES, seperti halnya terjadi di Selandia Baru (46\%); Brasil (20\%); dan Mesir $(38 \%)^{1,4,5}$

Ketidakpatuhan pada LES menyebabkan peningkatan angka kunjungan ke unit gawat darurat dan juga rawat inap, dengan dampak peningkatan beban fisik, psikis, sosial serta ekonomi yang harus ditanggung oleh odapus dan keluarganya. ${ }^{6}$ Mengingat dampak yang cukup penting, maka perlu dilakukan strategi pencegahan dan intervensi untuk mengatasi ketidakpatuhan pada LES. Strategi yang tepat dapat diawali dengan mengetahui bagaimana odapus dapat meminum obat sesuai standar penatalaksanaan yang dianjurkan oleh dokter.

Secara global, penelitian ketidakpatuhan pada lupus telah dilakukan di berbagai tempat dan menunjukkan hasil yang sangat kompleks dan berbeda dari satu negara dengan negara lainnya karena cenderung dipengaruhi oleh budaya, sistem kesehatan, lingkungan sosial, ekonomi maupun politik. Keadaan di Indonesia berupa tingkat sosial ekonomi yang rendah dan belum merata jaminan kesehatan yang dimiliki; kondisi geografis berupa negara kepulauan; tingkat pengetahuan terkait sistem penatalaksanaan penyakit kronik pada umumnya yang masih bersifat symptom focused, yaitu kecenderungan pelayanan layaknya penyakit akut yang memiliki sifat reaktif, jangka pendek, dan fokus pada terapi, ini merupakan potensi meningkatnya ketidakpatuhan minum obat.

Penelitian di Amerika Serikat dan Mesir menunjukkan bahwa karakteristik pasien, status perkawinan, pendidikan, domisili, status sosial ekonomi, efek samping dan efektivitas obat, jumlah obat perhari, penyulit penyakit, informasi dokter, pengetahuan, biaya, serta kesibukan odapus yang tinggi adalah faktor-faktor yang memengaruhi kepatuhan minum obat pada pasien LES. ${ }^{2,3,5,7}$.
Estimasi jumlah odapus di Jawa Barat jika dihitung menggunakan angka prevalensi di AmerikaSerikat (52/100.000) terdapatlebih dari 30.000 odapus ${ }^{8,9}$. Rumah Sakit (RSUP) Dr. Hasan Sadikin Bandung sebagai fasilitas pelayanan kesehatan tersier yang menjadi pusat rujukan di Provinsi Jawa Barat memiliki fasilitas yang sesuai dengan standar Perhimpunan Reumatologi Indonesia untuk menegakkan diagnosis dan penatalaksanaan lupus, yaitu fasilitas dokter subspesialis reumatologi serta laboratorium pemeriksaan imunologi dengan jumlah pasien LES yang telah tecatat sebanyak 520 orang. ${ }^{8,9}$ Penelitian ini bertujuan untuk mengeksplorasi pelaksanaan minum obat dengan harapan dapat diketahuinya pembentukan sikap serta perilaku pada pasien LES dalam pengobatan. Gambaran yang dihasilkan diharapkan dapat digunakan untuk memperbaiki penatalaksanaan LES yang berdampak pada peningkatan kualitas hidup serta penurunan angka kematian karena LES. Ketiga hal tersebut menjadi alasan pemilihan tempat penelitian di RSUP Dr. Hasan Sadikin Bandung.

\section{Metode}

Penelitian dilaksanakan dengan persetujuan dari Komite Etik Penelitian Kesehatan Fakultas Kedokteran Universitas Padjadjaran melalui Ethical Approval Nomor 412/UN6.C1.3.2/KEPK/ $\mathrm{PN} / 2016$. Informan dalam penelitian ini adalah pasien rawat jalan di klinik reumatologi RSUP Dr. Hasan Sadikin pada bulan Juli hingga September 2016 dengan kriteria inklusi, yaitu suku Sunda, terdiagnosis lupus minimal selama satu tahun dengan menggunakan kriteria Systemic Lupus International Collaborating Clinics (SLICC), sedang mengonsumsi obat lupus, dan bersedia mengikuti penelitian. Kriteria eksklusi adalah: pasien sedang hamil dan menyusui, menderita gangguan penglihatan berat, dan menderita gangguan pendengaran berat.

Pengumpulan data dilakukan dengan cara wawancara mendalam atau indepth interview mempergunakan panduan wawancara open question berdasar atas teori perilaku Lawrence Green kepada informan hingga terjadi kejenuhan data. Partisipan triangulasi adalah keluarga pasien dan dokter konsultan yang bertugas di klinik Reumatologi RSUP Dr. Hasan Sadikin Bandung. Proses wawancara mempergunakan catatan lapangan (field note), kamera foto, dan alat perekam sebagai alat bantu pengumpulan informasi yang diperlukan. 
Paradigma penelitian adalah constructivism untuk mengeksplorasi bagaimana pelaksanaan dan juga kepatuhan minum obat pada pasien LES sehingga dapat diketahui berbagai keadaan yang bembangun sikap, untuk selanjutnya menimbulkan perilaku kepatuhan dari informan. Analisis data dilakukan secara langsung pada tahap awal, tengah maupun akhir proses pengumpulan data untuk menghindari data sisa. Proses analisis dilakukan secara manual melalui tahapan transkripsi, reduksi, koding, kategorisasi, penyusunan tema, dan interpretasi data, serta theorizing. Keabsahan penelitian diuji dengan proses credibility (triangulasi dan membercheck), transferability (membuat uraian rinci), dependability (audit), dan confirmability (debriefing) dengan tujuan diperoleh data yang valid, reliable serta terurai secara rinci.

\section{Hasil}

Hasil penelitian menunjukkan seluruh informan odapus bersuku Sunda dan berjenis kelamin perempuan dalam usia produktif antara 21 sampai 42 tahun. Empat responden berdomisili di Kota Bandung, 1 di kota Cimahi, sedangkan satu responden lainnya berdomisili di Kabupaten Bandung. Seluruh responden telah terdiagnosis lupus dalam jangka waktu lama, masing-masing satu orang telah terdiagnosis selama 15 tahun, 11 tahun, 8 tahun, dan 3 tahun, sedangkan 2 responden lain masing-masing telah terdiagnosis selama 4 tahun (Tabel).

Dari pengolahan data dihasilkan 57 koding dikelompokkan dalam 14 kategori, kemudian diklasifikasikan menjadi 3 tema berdasar atas teori perilaku Lawrence Green, yaitu predisposing, enabling, dan reinforcing (Gambar 1). Kepatuhan minum obat hasil penelitian memiliki struktur dan keterkaitan dituangkan dalam bentuk peta konsep (Gambar 2). Peta konsep yang dihasilkan menunjukkan bahwa sikap odapus terhadap penyakitnya berdampak pada kepatuhan minum obat dilandasi oleh nilai hidup yang terdiri dari kepribadian, regulasi diri serta perasaan odapus tentang penerimaan terhadap penyakitnya. Selain itu, sikap ini ditentukan juga oleh ada kemudahan dan kenyamanan dalam menangani penyakitnya yang merupakan suatu pengalaman bagi odapus untuk melakukan pengobatan kembali di fasilitas kesehatan. Berbagai dukungan dari lingkungan terdekat, seperti pasangan, keluarga, teman, lembaga serta sikap tenaga kesehatan memotivasi dan secara langsung juga meningkatkan pengetahuan odapus terhadap
Tabel Karakteristik Informan

\begin{tabular}{|c|c|}
\hline Karakteristik & $\begin{array}{c}\text { Frekuensi } \\
\quad(n=6)\end{array}$ \\
\hline \multicolumn{2}{|l|}{ Jenis Kelamin } \\
\hline Perempuan & 6 \\
\hline \multicolumn{2}{|l|}{ Status Pernikahan } \\
\hline Menikah & 2 \\
\hline Belum Menikah & 4 \\
\hline \multicolumn{2}{|l|}{ Asal Domisili } \\
\hline Kota Bandung & 4 \\
\hline Kota Cimahi & 1 \\
\hline Kab Bandung & 1 \\
\hline \multicolumn{2}{|l|}{ Usia } \\
\hline 21-30 & 2 \\
\hline $31-40$ & 3 \\
\hline $41-50$ & 1 \\
\hline \multicolumn{2}{|l|}{ Pendidikan } \\
\hline SMA & 5 \\
\hline Perguruan tinggi & 1 \\
\hline \multicolumn{2}{|l|}{ Pekerjaan } \\
\hline Pegawai swasta & 2 \\
\hline Ibu rumah tangga & 1 \\
\hline Lain-lain & 3 \\
\hline \multicolumn{2}{|c|}{ Lama terdiagnosis lupus } \\
\hline $1-5$ tahun & 3 \\
\hline 6-10 tahun & 1 \\
\hline 11-15 tahun & 2 \\
\hline
\end{tabular}

penatalaksanaan penanggulangan penyakitnya. Eksperimen dan pengetahuan tersebut dapat menguatkan sikap odapus untuk berperilaku patuh atau tidak patuh minum obat.

\section{Pembahasan}

Penelitian di Indonesia menemukan bukti empiris bahwa odapus yang tidak dapat menyesuaikan diri terhadap keadaan penyakit, akan kesulitan untuk patuh minum obat. ${ }^{10}$ Hal tersebut sesuai dengan hasil penelitian yang menjelaskan bahwa sikap odapus yang berdampak pada kepatuhan merupakan hasil dari proses dalam kepribadian, regulasi diri dan juga perasaan odapus dalam beradaptasi dengan penyakitnya.

Sikap tersebut berdasar atas hasil penelitian 
adalah suatu tendensi atau kesiapan odapus untuk melakukan kegiatan pada kepatuhan, berupa manajemen konsumsi terdiri atas kesinambungan ketersediaan obat dan kepastian tatacara mengonsumsinya. Hal ini sesuai dengan anjuran manajemen konsumsi pada penyandang penyakit reumathoid berupa penggunaan kotak obat, kalender, alarm, serta persediaan obat. ${ }^{3}$
Selain itu, sikap diri juga dapat memengaruhi keinginan odapus mulai mencoba tidak patuh atau disebut sebagai proses eksperimen serta motivasi untuk meningkatkan pengetahuan tentang lupus. Penelitian di Amerika Serikat pada pasien LES yang tidak memiliki pengetahuan mengenai tujuan, manfaat, dan efek samping obat akan cenderung tidak patuh. ${ }^{3}$ Hal tersebut

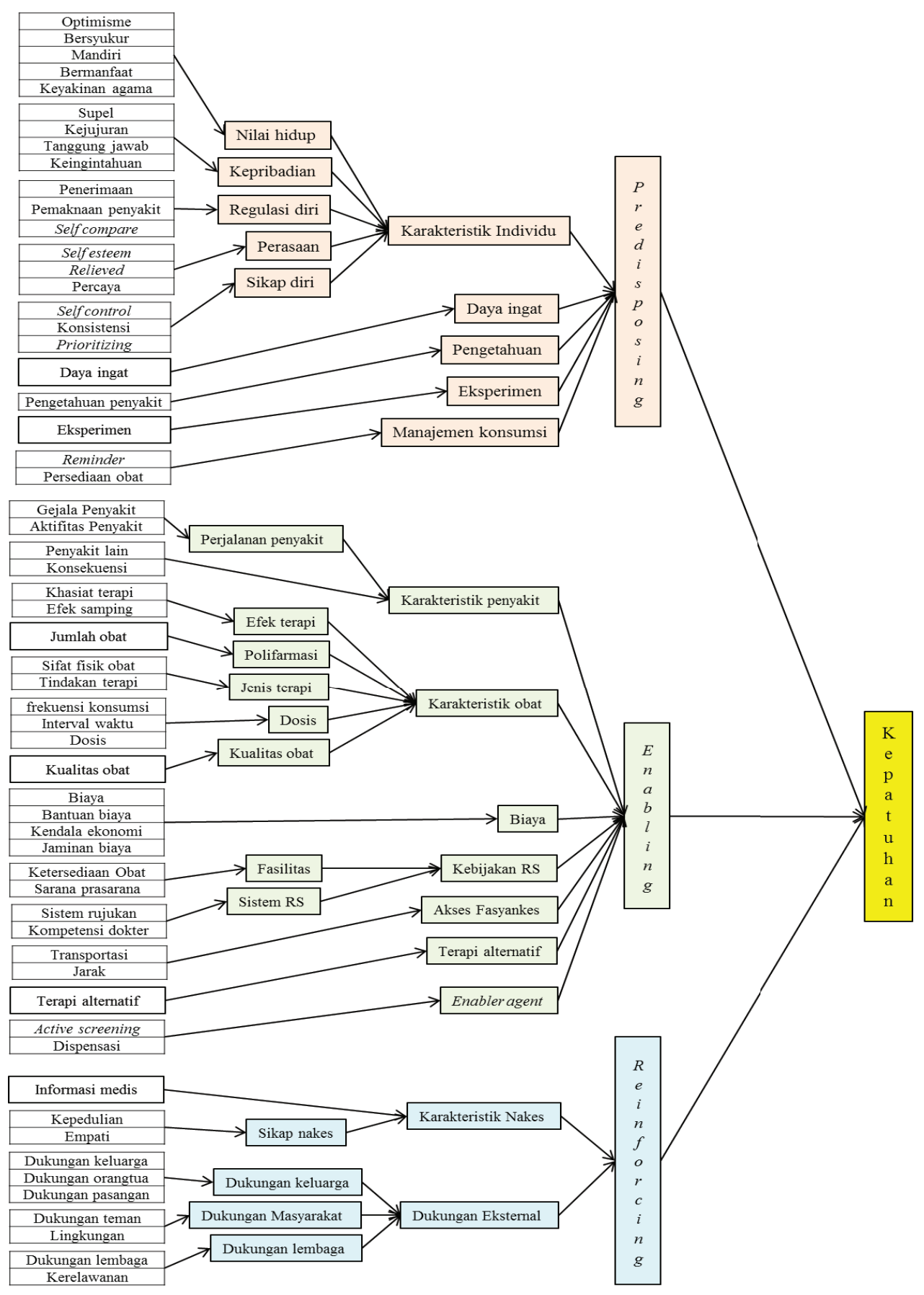

Gambar 1 Kepatuhan Minum Obat Pada Pasien Lupus 


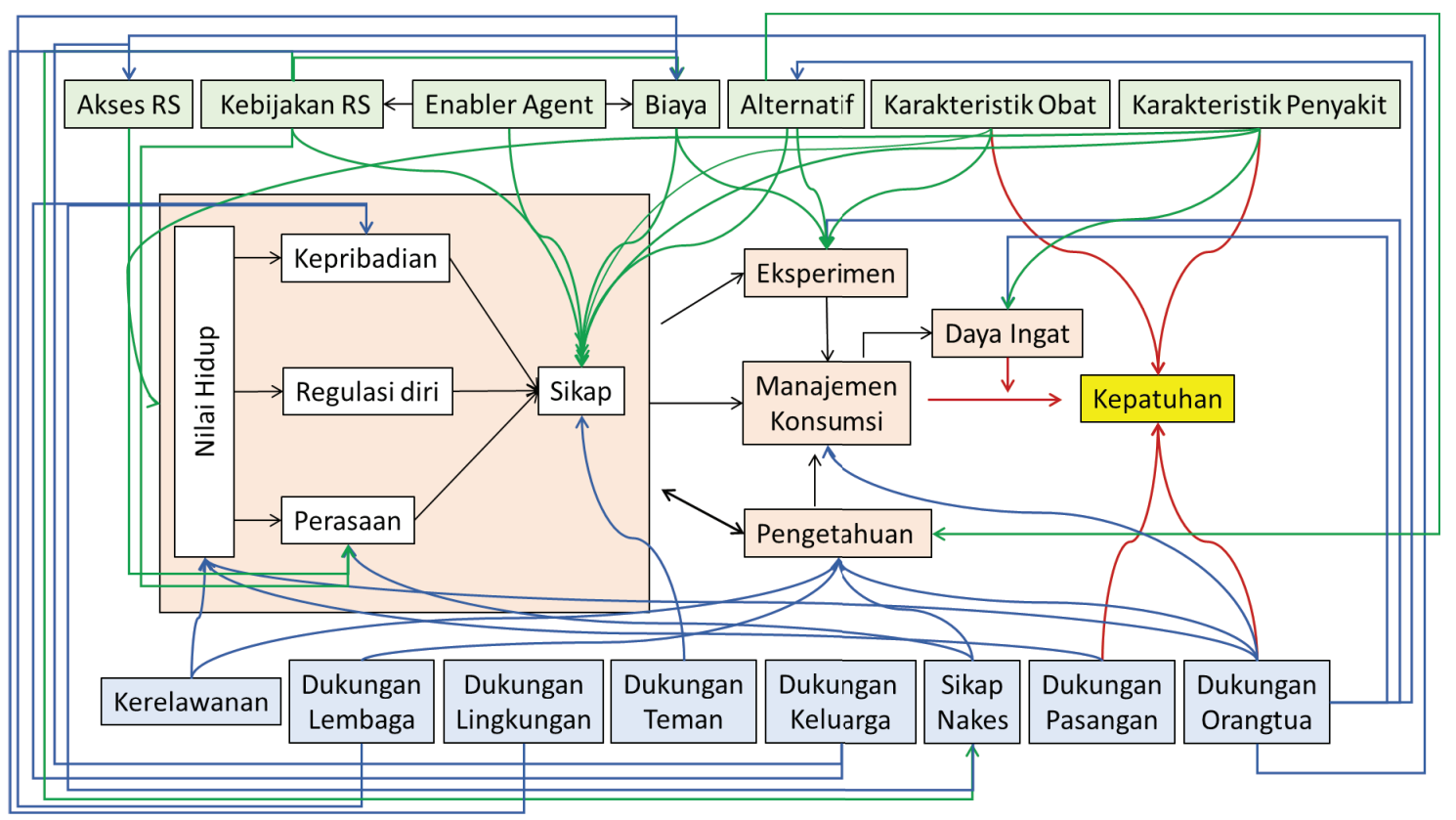

\section{Gambar 2 Peta Konsep Kepatuhan Minum Obat Pada Pasien Lupus di Poliklinik RSUP Dr. Hasan Sadikin Bandung \\ Keterangan:

$\begin{aligned} & \text { : predisposing } \\ & \text { : enabling } \\ & \text { : reinforcing } \\ \longrightarrow & : \text { Hubungan langsung terhadap kepatuhan } \\ \longrightarrow & : \text { Hubungan dari kategori dalam predisposing } \\ \longrightarrow & : \text { Hubungan dari kategori dalam enabling } \\ \longrightarrow & \text { : Hubungan dari kategori dalam reinforcing }\end{aligned}$

tidak sesuai dengan penelitian yang telah dilakukan yang menunjukkan bahwa hubungan pengetahuan dengan kepatuhan ibarat pisau bermata dua, yaitu dapat meningkatkan atau menurunkan motif kepatuhan. Perbedaan ini terjadi karena perbedaan lokasi penelitian yang menimbulkan perbedaan karakteristik subjek penelitian dan juga karakteristik nakes sehingga terjadi perbedaan informasi yang diterima oleh odapus.

Daya ingat dalam peta konsep itu terlihat berdampak langsung terhadap kepatuhan karena persiapan apapun yang telah dilakukan odapus untuk patuh minum obat akan gagal jika odapus tidak mampu mengingat saatnya minum obat. Daya ingat seorang odapus sangat mendukung dalam kepatuhan minum obat pada odapus sesuai dengan karakteristik penyakit lupus yang dapat bermanifestasi pada susunan saraf pusat dengan salah satu gejala berkurangnya daya ingat hingga demensia. ${ }^{11}$ Peran penting daya ingat berdasar atas hasil penelitian sesuai dengan penelitian terhadap pasien HIV, penyakit paru obstruktif dan pasien berusia lanjut telah menunjukkan bahwa daya ingat terbukti dapat berhubungan dengan kepatuhan minum obat. ${ }^{12}$

Karakteristik obat dan karakteristik penyakit sebagai bagian dari dukungan kemudahan dan kenyamanan odapus dalam mengonsumsi obat dapat secara langsung menentukan kepatuhan seorang odapus seperti terlihat pada peta konsep (Gambar 2). Berbagai penelitian terkait karakteristik obat pada pasien LES menunjukkan bahwa efek samping dan efektivitas obat, jumlah obat, dan juga frekuensi minum obat memiliki pengaruh terhadap kepatuhan odapus. , $3,5,7^{\mathrm{Hal}}$ tersebut sesuai dengan hasil penelitian yang juga menunjukkan bahwa karakteristik obat yang terdiri atas efek obat (khasiat dan efek samping) merupakan komponen dominan dan karakteristik fisik obat (jumlah, jenis, dan dosis obat), mendukung sikap dan perilaku kepatuhan Odapus dalam mengkonsumsi obat. Odapus akan langsung mengurangi atau menghentikan obat lupusnya ketika merasakan efek samping obat.

Keadaaan lain yang mendukung langsung kepatuhan adalah karakteristik penyakitnya. Karakteristik penyakit lupus menjadi ciri 
spesifik dalam penelitian ini karena belum tentu dapat diadaptasikan pada penyakit lain. Salah satu penelitian pada pasien LES menunjukkan bahwa ketidakpatuhan dipengaruhi oleh seluruh variabel karakteristik penyakit berupa durasi penyakit yang lebih pendek, aktivitas penyakit, dan kekambuhan dalam tiga bulan terakhir. ${ }^{2}$ Adapun hasil penelitian ini menunjukkan bahwa karakteristik penyakit yang tereksplorasi adalah aktivitas penyakit, komplikasi, dan kegawatan yang dapat mengancam jiwa. Gejala yang muncul sebagai konsekuensi ketidakpatuhan, baik yang pernah dialami maupun sebatas pengetahuan juga dapat meningkatkan kepatuhan odapus.

Reinforcing dalam peta konsep digambarkan sebagai dasar memperkuat proses kepatuhan odapus, yaitu berupa dukungan atau hukuman sosial dari orang-orang sekitar dan lingkungan. Dukungan utama yang langsung menimbulkan sikap positif atau negatif terhadap kepatuhan odapus yang belum menikah untuk meminum obat datang dari orangtua, sedangkan pada odapus yang telah menikah dukungan pasangan menjadi penting. Dukungan tersebut dibutuhkan terutama saat odapus memiliki keterbatasan fisik akibat dari penyakit lupusnya. Penelitian tentang dukungan keluarga terhadap kepatuhan minum obat pada pasien lupus di Amerika Serikat menyatakan status tidak menikah berhubungan dengan ketidakpatuhan, sedangkan penelitian di Indonesia pada penderita penyakit HIV dan TBC menunjukkan bahwa dukungan keluarga, teman, dan Lembaga swadaya masyarakat atau LSM memengaruhi kepatuhan.,13-15 Demikian pula hasil penelitian pada odapus menunjukkan bahwa dukungan-dukungan dapat meningkatkan motivasi kepatuhan odapus, yaitu orang tua, pasangan, keluarga, teman, lingkungan, dan lembaga termasuk sukarelawan.

Komponen reinforcing selanjutnya yaitu sikap tenaga kesehatan (nakes) yang memberikan pelayanan kepada odapus. Hasil penelitian ini memperlihatkan bahwa sikap nakes berupa empati dan kepedulian sangatlah menentukan perasaan odapus, namun tidak mengurangi motivasi kepatuhan oleh karena tidak terdapat pilihan fasilitas kesehatan lain. Hal tersebut terjadi terkait dengan fungsi dan keberadaan RSUP Dr. Hasan Sadikin sebagai rumah sakit pendidikan dan pusat rujukan tersier di Jawa Barat. Berbagai kendala yang dihadapi odapus yang berhubungan dengan sikap nakes, kebijakan rumah sakit, sarana prasarana, jarak tempuh, serta ketidaknyamanan selama perjalanan, ini menjadi keterpaksaan yang harus diterima dan hanya terhubung dengan perasaan dan sikap tanpa memengaruhi kepatuhan secara langsung.

Penelitian mengenai dukungan sikap nakes kepada kepatuhan, baik pada lupus maupun penyakit kronik lainnya di Indonesia belum ditemukan, namun sikap nakes dapat dikaitkan dengan kualitas komunikasi dokter dan pasien. Keadaan ini sejalan dengan salah satu dimensi kepatuhan menurut World Health Organization (WHO) yang menyebutkan bahwa hubungan yang baik antara pasien dengan tenaga kesehatan dapat meningkatkan kepatuhan. ${ }^{16}$ Komunikasi antara dokter dan pasien yang baik juga dapat meningkatkan kepercayaan pasien terhadap sistem kesehatan yang juga berdampak pada kepatuhan. $^{17}$

Karakteristik individu yang menjadi dasar kepatuhan bersifat spesifik dan lokal untuk masyarakat Jawa Barat khususnya karakteristik adat dan budaya Sunda sesuai dengan lokasi penelitian dan suku bangsa seluruh informan. Karakteristik suku bangsa Sunda yang religius dengan mayoritas pemeluk agama Islam yang menyebabkan keyakinan agama menjadi dasar penting dalam setiap alasan, motif, tindakan, dan evaluasi perilaku yang memiliki hubungan dengan kepatuhan. ${ }^{18}$ Sifat masyarakat sunda yang menjunjung tinggi tatakrama dan sopan santun serta masih memandang adanya strata sosial adalah hal yang memengaruhi kejujuran dan keingintahuan, yaitu menimbulkan rasa sungkan untuk bertanya atau berterus terang karena menganggap dokter mempunyai status sosial yang lebih tinggi ${ }^{18}$. Keramahan serta menerima keadaaan adalah sifat lain masyarakat Sunda yang memengaruhi kentalnya pengaruh karakteristik individu di dalam penelitian ini terutama terhadap konstruk kepribadian supel dan penerimaan. Pengaruh latar belakang adat dan budaya Sunda menyebabkan konsep dan konstruk dalam penelitian ini membangun konstruk lokal berlatar belakang karakteristik Sunda yang mungkin tidak ditemukan di tempat lain $^{18}$.

Komponen biaya pada penyakit lupus ini merupakan komponen yang penting meskipun hampir semua odapus yang berobat ke RSUP Dr. Hasan Sadikin memiliki jaminan kesehatan melalui Badan Penyelenggaraan Jaminan Sosial (BPJS) kesehatan, karena jaminan kesehatan tidak dapat memenuhi seluruh biaya pengobatan yang dibutuhkan. Menurut WHO, komponen biaya tidak secara konsisten ditemukan sebagai prediktor kepatuhan namun rendahnya status ekonomi di negara berkembang menyebabkan pasien berada dalam posisi memilih prioritas yang lebih penting, misalnya untuk kebutuhan 
pangan. ${ }^{16}$ Penelitian yang terkait dengan faktor biaya pada pasien lupus di Amerika Serikat dan Mesir menyatakan salah satu determinan ketidakpatuhan yang bermakna adalah status ekonomi. ${ }^{2,5}$ Di Indonesia belum ditemukan penelitian determinan kepatuhan lupus, namun pada penelitian determinan kepatuhan HIV dan TBC menyatakan bahwa biaya merupakan salah satu faktor penting. ${ }^{13-15}$

Berdasar atas hasil penelitian ini disimpulkan determinan kepatuhan minum obat pada pasien lupus di RSUP Dr. Hasan Sadikin Bandung memakai teori perilaku Lawrence Green sebagai predetermined theme berupa predisposing, enabling, dan reinforcing adalah sebagai berikut: individu, daya ingat, pengetahuan, eksperimen, dan juga manajemen konsumsi (predisposing); karakteristik penyakit, karakteristik obat, biaya, kebijakan rumah sakit, akses ke rumah sakit, terapi alternatif, dan enabler agent (enabling); karakteristik tenaga kesehatan dan dukungan eksternal dari berbagai pihak (reinforcing). Konsep-konsep dan konstruk yang ditemukan membangun konstruk lokal Jawa Barat berlatar belakang karakteristik masyarakat Sunda dan bersifat kontekstual terhadap penyakit lupus.

Dari hasil ekplorasi dan juga pembahasan pelaksanaan minum obat dapat disimpulkan terdapat gambaran peta konsep sikap odapus suku Sunda di RSUP Dr. Hasan Sadikin Bandung berdasar atas nilai hidup meliputi kepribadian, regulasi diri yang membentuk sikap odapus terhadap kepatuhan minum obat. Dukungan pelayanan kesehatan dalam hal ini Rumah Sakit serta obat yang diterima merupakan pengalaman, sedangkan dukungan nakes serta keluarga dekat dan lingkungan sekitarnya dapat menambah pengetahuan dalam manajemen konsumsi obat seorang odapus yang selanjutnya menentukan perilaku kepatuhan odapus dalam minum obat. Dilanjutkan dengan penelitian kuantitatif untuk pembuktian lebih lanjut dari berbagai hasil yang diperoleh dalam penelitian kualitatif.

\section{Daftar Pustaka}

1. Kang SC, Hwang SJ, Chang YS, Chou CT,Tsai CY. Characteristics of comorbidities and costs among patients who died from Systemic Lupus Erythematosus in Taiwan. Arch Med Sci. 2012; 8(4): 690-6.

2. Julian LJ, Yoolin E, Yazdany J, Panopalis P, Trupin L, Criswell LA, dkk. Depression, medication adherence and service utilization in Systemic lupus erythematosus. Arthritis
Rheum. 2009;62(2):240-6. .

3. de Achaval S, Suarez-Almazor ME. Treatment adherence to disease-modifying antirheumatic drugs in patients with rheumatoid arthritis and Systemic Lupus Erythematosus. Int J Clin Rheumtol. 2010;1;(3):313-26.

4. Bugni MV, Ozaki SS, Okamoto KYK. Factors associated with adherence to treatment in children and adolescents with chronic rheumatic diseases. J Pediatr (Rio J). 2012; 88(6):483-8.

5. Abdul-Sattar AB, Abou El Magd SA. Determinants of medication non-adherence in Egyptian patients with systemic lupus erythematosus: Sharkia Governorate. Rheumatol Int. 2015;35(6):1045-51.

6. Feldman $\mathrm{CH}$, Yazdany J, Guan H, Solomon $\mathrm{DH}$, Costenbader KH. Medication nonadherence is associated with increased subsequent acute care utilization among medicaid beneficiaries with Systemic Lupus Erythematosus. Arthritis Care Res. 2015; 67(12):1712-21

7. Koneru S, Kocharla L, Higgins GC, Ware A, Passo MH, Farhey YD, dkk. Adherence to medications in systemic lupus erythematosus. JClin Rheumatol 2008;14(4): 195-201.

8. Badan Pusat Statistik Kota Bandung. Statistik daerah kota Bandung 2015. [diunduh 27 November 2015] Tersedia dari: www. bandungkota.bps.go.id.

9. Perhimpunan Reumatologi Indonesia. Rekomendasi perhimpunan reumatologi Indonesia untuk diagnosis dan pengelolaan lupus eritematosus sistemik. Jakarta: Perhimpunan Reumatologi Indonesia; 2011.

10. Paramita R, Margaretha. Pengaruh penerimaan diri terhadap penyesuaian diri pada penderita lupus. Jurnal Psikologi. 2013; 12(1):1-8.

11. Joseph FG, Scolding NJ. Neurolupus. Pract Neurol. 2010;10(1):4-15

12. Horne R, Weinman J, Barber N, Kellar I Concordance, adherence and compliance in medicine taking. London: National Coordinating Centre for NHS Service Delivery and Organisation. 2005.

13. Yuniar Y, Handayani RS, Aryastami NK. Faktor-faktor pendukung kepatuhan orang dengan HIV AIDS (ODHA) dalam minum obat antiretroviral di kota Bandung dan Cimahi. Buletin Penelitian Kesehatan 2013; 41(2):73-83.

14. Sugiharti, Yuniar Y, Lestary H. Gambaran 
kepatuhan orang dengan HIV AIDS (ODHA) dalam minum obat ARV di kota Bandung tahun 2011-2012. Buletin Penelitian Kesehatan. 2014;5(2):1-11.

15. Nugroho RA. Studi kualitatif faktor yang melatarbelakangi drop out pengobatan tuberkulosis paru. Kemas. 2011;7(1): 83-90.

16. Pasma A, van't Spijker A, Hazes JM, Busschbach JJ, Luime JJ. Factors associated with adherence to pharmaceutical treatment for rheumatoid arthritis patients:
Asystematic review. Semin Arthritis Rheum. 2013;43(1):18-28

17. Elder K, Ramamonjiarivelo Z, Wilthhire J, Piper C, Horn WS, Gilbert KL, dkk. Trust, Medication Adherence, and Hypertension Control in Southern African American Men. Am J Public Health. 102(12):2242-5.

18. Ekadjati ES. Kebudayaan Sunda; suatu pendekatan sejarah. Bandung: Dunia Pustaka Jaya; 2014. 